\section{Dragiša Veličković}

Singidunum Universityl Belgrade

Jelena Veličković

Business school of applied studies ${ }^{2}$, Blace
SCIENTIFIC REVIEW ARTICLE doi:10.5937/ekonomika1602061V

Received: February 20, 2016

Accepted: April 13, 2016

\title{
INTEREST RATEST AND GROWT IN DEVELOPING COUNTRIES
}

\begin{abstract}
When developing countries begin to raise the trajectory of long-term development, interest rates and local currencies grow higher. An increase in the real cost of capital, a decline in investment demands, as the IS-LM model envisages, may jeopardize growth.

Can the interest rate policy be used to efficiently manage aggregate demand to sustain the initiated growth? It has proved quite successful at higher interest rate policy levels of development. In underdeveloped countries, this is not the case.

Developing countries largely fail to succeed in ensuring the full operation of market mechanisms. Their financial market is underdeveloped, capital demand is chronically high, and therefore the manipulation of the discount rate is of little use. In recession, manipulating government expenditures, implementing deficit financing and controlling private and public consumption prove to be more efficient anti-recession instruments.

Economic policy ought to provide a favorable environment for achieving developmental objectives: relative price stability and favorable interest rates. Underdeveloped countries need to control, channel and impose certain restrictions. The liberalization of capital transactions must not precede full convertibility of the local currency
\end{abstract}

Keywords: growth, interest rates, developing countries

JEL classification: O16, O20, O23

\section{КАМАТЕ И РАСТ У ЗЕМЉАМА У РАЗВОЈУ}

\section{Апстракт}

Кад недовољно развијене земље почну да подижу путању дугорочног раста, каматне стопе и вредност домаће валуте расту. Раст реалног трошка капитала и пад тражње за инвестииијама, како то IS-LM модел предвиђа, могу да угрозе раст.

Да ли се политиком каматних стопа може ефикасно управљати агрегатном тражьом како би се одржао започети раст? На вишим нивоима

\footnotetext{
${ }^{1}$ dvelickovic@singidunum.ac.rs

2 jelenavelickovic409@yahoo.com
} 
развијености политика каматних стопа се може користити са прилично успеха. У недовољно развијеним земљама то није случај.

Земље у развоју углавном не успевају да омогуће пуно функиионисане тржишних механизама. Њихово финансијско тржсите је неразвијено, тражна капитала хронично увећана, па манипулисање есконтном стопом не може да буде од веће помоћи. У рецесији, манипулисање државним расходима, примена дефицитарног финансирања и контрола приватне и јавне потрошње ефикаснија су антирецесиона средства.

Економска политика треба да обезбеди повољан амбијент за остварење развојних ичиљева: релативну стабилност иена и подстицајне каматне стопе. Недовољно развијене земље капиталне трансакиије морају да контролишу, каналишу и намећу одређена ограничења. Либерализачија капиталних трансакиија не сме да претходи пуној конвертибилности домаће валуте.

Кључне речи: раст, каматне стопе, земље у развоју.

\section{Introduction}

Different countries attain different levels of development and growth rates. Neoclassical economics (Bukvić, R., Pavlović, R., 2014. p. 2.) looks at economic growth, or development, as a process that happens automatically and arises fully from the games market.

Growth rates vary from period to period. Contrary to the identified empirical facts, the endogenous model of growth presupposes that all countries share the same long run growth rate, determined by the growth rate of the world technology frontier.

The difference in growth rates is explained by transitional dynamics. In an attempt to change the position in the long run global GDP distribution, some economies record growth at different rates. Underdeveloped countries take an inferior position in the global GDP distribution and as a rule are below the equilibrium trajectory of growth. It is interesting to observe what is happening in the markets at times when they try to increase their share in distribution.

A shift to the market organization of economic activities, an increase in investments or transfer of technologies from developed countries can take economy back to the long-run path of development or even raise the economy above it. Investment growth is particularly interesting because it plays a decisive role in the development of local products. The role is twofold. On the one hand, it affects an increase in demand because it is a prerequisite for economic production increase. At the same time, investment consumption, as a part of overall consumption, via demand, in the process described as the multiplier, also boosts aggregate demand. Progressive investment growth affects precipitate income trajectory leap. This particularly refers to underdeveloped countries. From the aspect of their developmental potentials, investments are the most important segment of aggregate demand.

Most authors (Batini, 2009, Clarida, 2001, Krugman, 2014, Mankiw, 2009) comparing flexible and fixed regimes conclude that the floating exchange rates are 
preferable. Krugman, consider the autonomy of the monetary policy (better ability to control money supply) to be an important advantage of floating exchange rates. But, the basic question that arises here is whether aggregate demand may be efficiently used to manage an interest rate policy?

Independent of the level of development, it is known that short run rise in interest rates influences the growth of real cost of capital. Therefore, the changes in interest rates caused by the monetary policy measures have an effect on investment demand. However, increased investment demand also affects interest rate levels. What is the nature of this relationship?

The analysis that follows relies on the analysis of how the exchange market and loans market in developing countries functions. Ranges are clearly limited by the fact that these countries tend to have less developed markets. They are often informal or some of transactions take place in the gray zone. However, in this or that way, both markets are functioning.

\section{IS-LM model}

The model, in an open economy, is based on the simultaneous equilibrium in the goods market (IS curve) and money market (LM curve). It presupposes the givenness of GDP and the price level, which means that it doesn't deal any closer in these variables. But it is actually a rapid growth of GDP and general price level that are typical for fastdeveloping countries. In this sense, the model can be understood as a representation of the state of two markets in one point on the long-run growth trajectory.

The level of interest rates, investments and exchange rate are the main focus of attention of this model. We will show that on the rapid development trajectory the underdevelopment per se perpetuates a high level of interest rates and exchange rates.

IS curve represents the equilibrium of the goods market. The level of output is equal to the sum of consumption, investments, public spending and net exports (Blanchard, 2005, p. 422):

$$
Y=C(Y-T)+I(Y, i)+G+N X\left(Y, Y^{*}, E\right)
$$

where $Y$ - is at the same time domestic product and income, $Y^{*}$ - foreign product $C$ consumption, $T$ - taxes, $i$-interest rate, $E$ - exchange rate. Given that the period of time is short, the level of local and foreign prices is treated as given and constant so that there is no inflation either real or expected, nominal interest rate equals real interest rates and nominal exchange rate is equivalent to real exchange rate.

Consumption is the disposable income function (the difference between income and taxes). Investments depend on income and interest rate and net exports on domestic and foreign products and foreign exchange rate. The equality between money supply and demand determine the interest rate. The relation between domestic interest rate and foreign exchange rate is negative:

$$
E=\frac{E^{e}}{1+i-i^{*}}
$$


$E^{e}$ - the spot exchange rate, $E^{e}$ - expected, future exchange rate, $i^{*}$ - foreign interest rate. If the equation (2) is included in the equation (1) we get a relation that describes the balance in the goods market:

IS curve shows the relation between interest rate and output level. Interest rate is, therefore, considered an aggregate demand determinant. The correlative relation between the output and the level of interest rate is negative, which means that the IS curve slope is negative. High interest rates imply low investment and output levels. Changes in investments indicate a simultaneous change in aggregate demand and the output level. A low output level implies a relatively modest demand. A rise in the interest rate, besides the direct influence on a drop in demand and domestic product has the same effect, indirectly, through exchange rate.

The curve implies a given tax and public consumption levels. This implies that changes in one variable will cause a shift in IS curve. A tax increase shifts the curve towards left: at any given interest rate, tax increase lowers the domestic product equilibrium balance. The same applies to public consumption.

In the money market, interest rate is determined by money supply and demand equality:

$$
\frac{M}{P}=Y L(i)
$$

The equilibrium in the money market can be represented by the LM curve which is a geometric representation of different combinations of interest rates and output in which the money market is in equilibrium. The curve is derived from the equilibrium that characterizes the Keynesian money market model, and has a positive slope. Income growth increases the demand for money which in return increases equilibrium interest rate.

As the curve is based on the assumption that the real money supply is given, changes in the nominal quantity of money and the price level, shift the LM curve. An increase in the money supply lowers the interest rate shifting the curve downward, and vice versa.

The intersection of the two curves is characterized by the simultaneous equilibrium in the two markets. It defines the equilibrium domestic product and the equilibrium interest rate. With the given foreign interest rate and the expected future exchange rate, the equilibrium interest rate is determined by the equilibrium exchange rate.

\section{$I S-L M$ model in developing countries}

When it comes to developing countries this model has several weaknesses. First and foremost, it disregards the permanent presence of inflation and its influence on investment goods demand and overemphasizes the influence of the interest rate level on the investment level.

The model presupposes that investments are conditioned by the demand level i.e. by income and the nominal interest rate which is assumed to be equivalent to the real interest rate i.e.: 


$$
I=I(Y, r)
$$

If truth be told, a change in the price level is also taken in consideration and in the model it is reflected through accepting the nominal instead of the real interest rate. The real interest rate features as a difference between the nominal interest rate $i$ and expected inflation $\pi^{e}$ :

$$
I=I\left(Y, i-\pi^{e}\right)
$$

but it is expected that there is no inflation, neither real nor expected.

The equation shows that in inflationary economies the level of investments is not only determined by real interest rate level. The nominal interest rate and the level of expected inflation in the countries that raise long-term growth trajectory have quite an effect on the demand segment which is related to the level of investments. This relationship is particularly strong in developing countries where inflation is necessarily present.

The power of the connection can be shown as follows: If we disregard the amortization and assume that the price of an additional unit of capital (investment) depends on the interest on invested capital $i P_{I}$ (where $i$ is - the nominal interest rate and $P_{I}$ the price of capital goods), and changes in investment goods prices, the price of additional unit of capital (Babić, 1991, p. 236) will equal:

$$
\begin{aligned}
& P_{c}=i P_{I}-\frac{d P_{I}}{d t} \\
& P_{c}=P_{I}\left(i-\frac{1}{P_{I}} \frac{d P_{I}}{d t}\right)
\end{aligned}
$$

The real cost of capital depends on the price of capital goods, nominal interest rate and changes in investment goods $\frac{1}{P_{I}} \frac{d P_{I}}{d t}$. A rise in nominal interest rates generates an increase in real cost of capital: $\frac{d P_{c}}{d_{I}}=P_{I}>0$

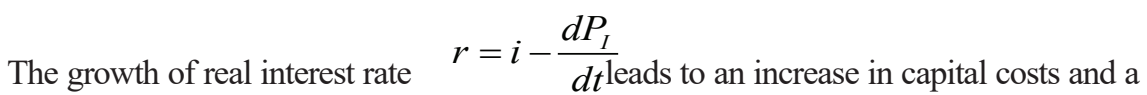
reduction in investment demands. However, the real interest rate is also determined by inflation rate. For the given nominal interest rate, the real interest rate is smaller as the rate of inflation measured by investment goods growth rate is higher. Therefore, a demand for investments in inflationary economies rises. This can be illustrated by the following inequality:

If investors expect an increase in the prices of investment goods, they are likely to step up their investments because they know that the funds they earmarked for investments in the future period will be worth less. A growth in demand for investment goods accelerates inflation and the gap between savings and investment deepens. In an open economy, with developed markets, this gap is closed by reducing the net capital outflow. In underdeveloped countries, with shallow capital markets, interest rates are more likely to rise, causing an inflationary spiral. 
In addition, in developing countries with underdeveloped financial markets where chronic shortage of capital is present, investments are generally inelastic to the interest rate level. Companies estimate future optimal level of capital funds and try to use investments to close the gap between the desired and the current level of capital in the shortest period of time. Investments rather pose a function of the gap between the desired and actual size of capital than an interest rate.

In the end we may conclude that investments are the function of the gap between the desired and actual size of capital $\left(\pi^{e}\right)$, income growth and expected inflation $\pi^{e}$ :

$$
I=I\left(\mathbf{Z}, \pi^{e}, Y\right)
$$

Money demand is chronically high and has little to do with interest rate. Such a situation in the market is favorable for the formation of high interest rates, which is good for raising the marginal propensity to save but is not good for investments.

To make this clearer, let us use Mankiew's graph (2008., p. 666) that besides the considered variables also includes net capital outflow, a variable that connects the two markets and points to an imbalance between the value of foreign assets bought by local residents and the value of domestic assets bought by foreigners. As a rule, in developing countries, net capital outflow is negative because their net export is also negative.

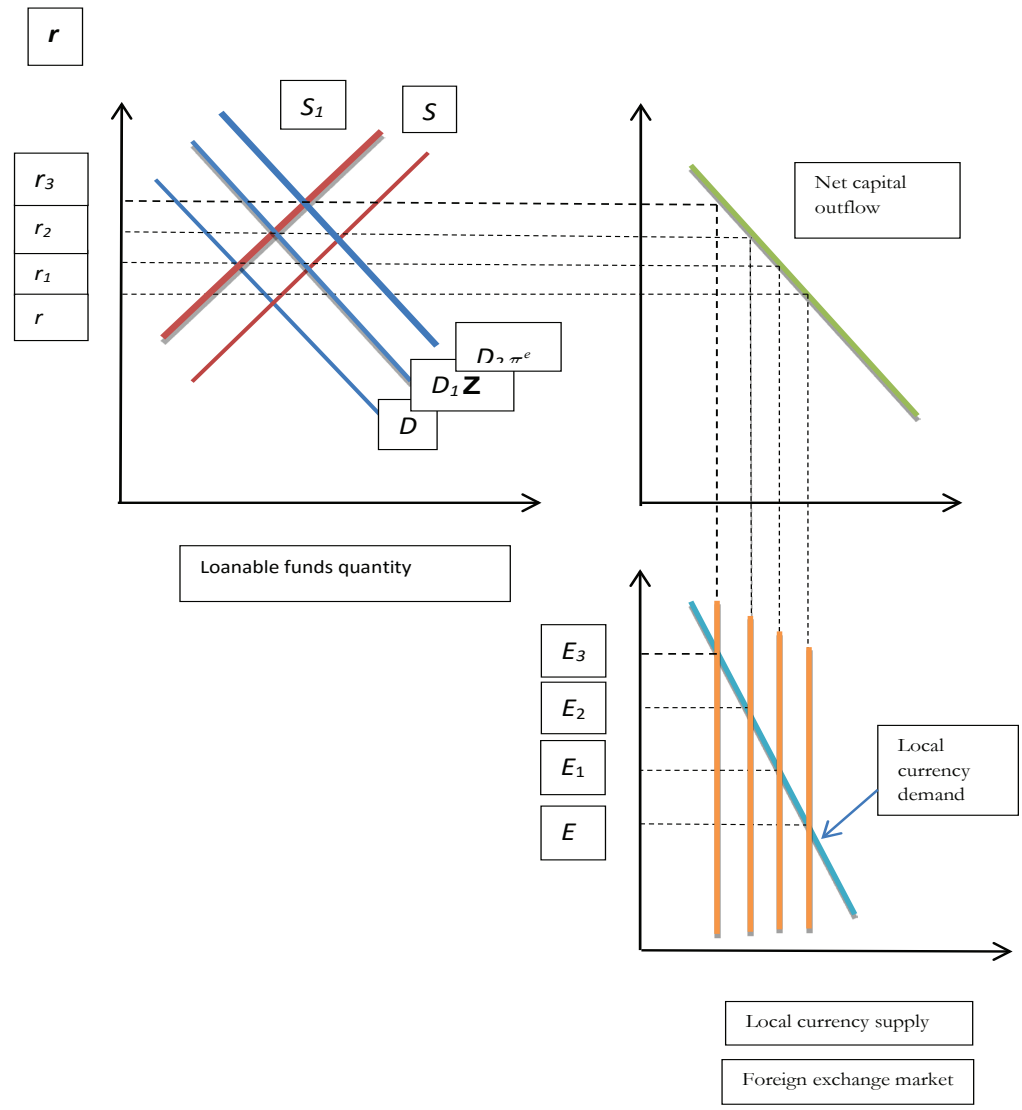


The position of the supply curve $(S)$ and the demand curve $(D)$ on the graph is typical for the countries whose economy is on the long-term growth trajectory. The relationship between supply and demand for loanable funds determines the equilibrium interest rate $(r)$.

When it comes to developing countries, the supply curve must be presented differently. Namely, the supply of loanable funds (resulting from national saving) in these countries is insufficient because the domestic saving (as a result of the low income level) is low. In the countries whose position in the distribution of world GDP is inferior, whose economies are beneath the trajectory and which are trying to reach a higher trajectory growth level, savings is, as a rule, low, and the supply curve is shifted to the left $\left(S_{1}\right)$, which means that from the beginning interest rates are higher $\left(r_{l}\right)$. In an open economy, investment in these conditions, can grow only if the net capital outflow increases (trade balance deficit also rises), which is possible if the country has a lot to offer to foreign investors. Such a scenario can be of use only if investment projects are implemented along with an increase in return on capital.

On the other hand, a demand for loanable funds in the countries that aspire to raise long-term growth trajectory is at a higher level, for two reasons. Efforts to close the gap ( $\mathbf{z}$ ) between the current and desired levels of capital determine the higher level of demand for any interest rate, which shifts the demand curve to the right. Demand is at the same time higher due to the net capital outflow, which tends to be more negative. The position of the curve changes from $(D)$ to $\left(D_{1}\right)$ and the interest rate rises to the level of $\left(r_{2}\right)$.

Investors are accustomed to the ever-present inflation and their expectations $\left(\pi^{e}\right.$ ) are in this regard significant. They estimate that the funds earmarked for investments will, in the coming period, be worth less and hence, independent of the interest rate level, they seek to promptly realize the investments. The demand curve is shifted further to the right, from the level $\left(D_{1}\right)$ to the level $\left(D_{2}\right)$. Interest rate increases from the level $\left(r_{2}\right)$ to the level $\left(r_{3}\right)$. The described interest rate growth jeopardizes investments and capital accumulation and consequently the rate of economic growth.

If a country has a budget deficit, and developing countries generally do, it will further shift the supply curve to the left, which will squeeze out domestic investment and cause a further rise in interest rates.

A rise in interest rates causes all the more negative net capital outflow. Consequently, the value of the local currency rises and so does the trade balance deficit. Instead of encouraging the export-oriented segment of economy, the local currency becomes increasingly favorable for importers. As net export equals net capital outflow, what is happening can be vividly described as the sale of local assets for the sake of importing foreign goods.

\section{The possibilities of monetary policy}

High interest rates are typical for the countries aspiring to achieve long-term growth. Such a situation is conducive to the marginal propensity to save, but is not conducive to investment growth. It is therefore natural to wonder to what extent can interest rate management in these countries affect the level of investments and price 
growth? Furthermore, are underdeveloped countries at all capable of efficiently controlling their interest rates?

At higher development levels of market-regulated economies with low inflation, this instrument can be used with reasonable success. In underdeveloped countries this is not the case. The higher the level of development and the lower the inflation, an increase in real interest rate level will have a greater influence on the decline in investments and vice versa. In underdeveloped countries in which expected inflation is a commonplace, a rise in real interest rates has very little influence on the aggregate demand level. This rise would have to be quite emphasized so that it could have an effect on a decline in both investment and aggregate demand. And vice versa, stimulating investments, employment and economic activities through a low inflation rate policy does not have such an effect on investment growth, as much as it takes the country into an inflationary spiral.

What happens when an expansionary monetary policy is being followed? At first glance, it appears that money supply increase can cause a multiplied domestic product growth. However, the described effect can only last a short period of time. Any subsequent attempt requires significantly bigger monetary expansion which increasingly raises prices and lowers production. Production revolves around "the potential rate," which is determined by real factors of production. Why? Because economic agents follow market trends and at the time when they are anticipating the growth of money supply, their behavior (based on experience) is adapted to those changes, and the impact of money supply growth on real income is absent. Only nominal indicators grow. This especially applies to the underdeveloped countries. They usually have a problem with inflation in the long run. Economic agents are accustomed to living with inflation and therefore much faster anticipate monetary expansion and hence more quickly adjust to it, which means that the effects of monetary growth melt much faster than in developed market economies. Because of this, an increase in the money supply cannot provide a more lasting economic boost.

If an underdeveloped country liberalizes capital transactions, a large number of economic agents realize their investment plans by incurring debts abroad at lower than the local rates. This puts additional pressure on the local foreign exchange market. A rise in convertible money supply makes local currency stronger. The central bank is not in a position to reject the rising convertible money supply. Constant pumping of the purchasing power makes the local currency appear stronger than it actually is. It's a good way to increase the county's external debt. In countries where, like in Serbia, exists dual currency economy, coupled with a high degree of liberalization of the capital transactions, that portion of total debt grows at a high rate. Central bank's maneuvering space, which enables us to conduct an adequate policy of local currency market supply, is declining. The monetary policy becomes ineffective.

If the main objective of the central bank is to maintain price stability, nothing else remains but to, by lowering repo operations, reduce money supply which further jeopardizes the work of the country's financial sector. It is more cost-effective for banks to purchase securities issued by the central bank than to fund largely unestablished companies, which also bears greater risk. And as long as the aforementioned money flows are directed towards an underdeveloped country, the exchange rate favors an increase in trade balance deficit. If and when money flow changes direction, the value of the domestic currency falls. However, this does not mean that such a trend will contribute 
to export growth. Export growth is determined by a number of factors, primarily by foreign demand. Among the most important is investment efficiency level financed in the previously described manner.

In underdeveloped countries a large portion of money supply is kept in the form of cash, thereby making multiplicative expansion of money, that is, credit contractions limited. However, in a two-currency economy, one of which is not convertible, where high liberalization level of capital transactions exists, an effort to lead an optimal money policy is burdened with additional restrictions. They are to a great extent determined by external factors.

At the very bottom of the cycle, when the crisis sets in and when it is necessary to boost economic activities, bringing interest rates down is the usual option. Such a policy is carried out with more or less success, again depending on the overall extent to which the market is developed. Attempts to overcome the crisis by implementing the policy of low interest rates, particularly if the policy is not accompanied by other measures, usually end without any significant results. Brining interest rates down is only successful if one condition is met, namely, the level of interest rates should not only be low, it should also be lower than an income decline rate.

For the less developed countries moderate inflationary pressure is a better way to control real interest rates and boost investment demand. This helps maintain the general "temperature" of economy at a slightly elevated level. Nevertheless, this policy should be carefully implemented. Increasing money supply can raise private at the expense of investment consumption or export and in that way jeopardize economic growth. Therefore, private consumption should be kept under control. This can be achieved by the selective credit policy, restrictive consumer loan policy and fiscal policy.

We may conclude that the degree of monetary policy effectiveness in developing countries that seek to rapidly raise long term development trajectory is low. Therefore, fiscal policy should be given advantage. In the described situation it is more efficient and represents a more important lever of economic policy. First and foremost, this refers to manipulating public expenditures and implementing deficit financing.

\section{Conclusion}

Encumbered with a large number of development-related problems, developing countries usually fail to pave the way for the full functioning of market mechanisms, which makes developmental processes more difficult to regulate. Their financial market is underdeveloped and capital demand is chronically high. The monetary, in concert with the fiscal policy, in the short run, or over several short-run time segments, i.e. in the long run, ought to provide a favorable environment for achieving long-term developmental goals. Favorable environment implies relative price stability and favorable interest rates. Both segments depend on a larger number of circumstances.

The high interest rate level is a result of expected inflation and an aspiration to close the gap between the current and desired level of capital, hence manipulating the discount rate is not very helpful. Ever-present inflation can be reduced, but the cost of bringing down the growth rate is too high.

When raising the growth trajectory, particularly in recession, rather than on monetary, these countries should base their economic policies on the instruments of 
fiscal policy and, above all, on controlling private and public consumption. Capital transactions must control, channel and impose certain restrictions. The liberalization of capital transactions must not precede full convertibility of the local currency.

\section{References}

Aghion, P., Howitt, P., (1999). Endogenuos Growth Theory, The MIT Press

Alen, R.G.D, (1970). Mathematical Economics, Mac Millan, London

Babić, M., (1991). Makroekonomski modeli, Narodne novine, Zagreb, 236.

Batini, N., Levine, P., \& Pearlman, J. (2009). Monetary and Fiscal Rules in an Emerging Small Open Economy. IMF Working Paper, WP/09/22.

Blanchard, O.,( 2005). Makroekonomija, Mate, Zagreb, 422.

Bukvic, R. (2014). Неокласична економска теорија и проблеми економског развоја (Neoclassical Economic Theory and the Problems of Economic Development). Ekonomika, 60(3), 1-19.

Chiang, A., (1994), Osnovne metode matematičke ekonomije, Mate, Zagreb

Clarida, R., Galí, J., \& Gerlter, M. (2001): Optimal Monetary Policy In Open Versus Closed Economies.

American Economic Review, 2001, v. 91 (2, May), 248-252.

Dennis, R. (2001). Monetary Policy and Exchange Rates in Small Open Economies, FRBSF Economic Letter.

Faia, E., \& Monacelli, T. (2008). Optimal Monetary Policy in a Small Open Economy with Home Bias. Journal of Money, Credit and Banking, 40, 4, 721-750.

Harcourt, G.C., Laing, N.F., (1971), Capital and Growth, Penguin Books, London

Krugman, P. R., Obstfeld, M., \& Melitz, M. (2014). International Economics: Theory \& Policy. Harlow, UK: Tenth Edition Pearson Education Limited.

Link, S., A., (2003).Technological Change and Economic Performance, Routledge, London and New York

Mankiw, G., Taylor, M.P., (2008). Ekonomija, Datastatus, Beograd, 666.

Romer, P., (1994). The Origins of Endogenous Growth, Journal of Economic Perspectives. 8 (Winter): 3-22

Sijben, J. (1976), Money and Economic Growth, Leiden

Solow, R.M., (1956). A Conteibution to the Theory of Economic Growth, Quarterly Journal of Economics, vol.70. 